CZASOPISMO INŻYNIERII LĄDOWEJ, ŚRODOWISKA I ARCHITEKTURY JOURNAL OF CIVIL ENGINEERING, ENVIRONMENT AND ARCHITECTURE

JCEEA, t. XXXIV, z. 64 (3/II/17), lipiec-wrzesień 2017, s. 57-66, DOI:10.7862/rb.2017.153

\author{
Janusz DĄBROWSKI ${ }^{1}$ \\ Waldemar PALUCH ${ }^{2}$
}

\title{
OKREŚLENIE SKUTKÓW REWITALIZACJI TERENÓW POWOJSKOWYCH NA DZIAŁALNOŚĆ KOMERCYJNĄ NA TERENIE MIASTA JAROSŁAWIA
}

\begin{abstract}
W pracy autorzy opisali proces uchwalania Miejscowego Planu Zagospodarowania Przestrzennego terenów po byłej jednostce wojskowej. Blisko 4 ha powierzchni w ścisłym centrum miasta zostało zakupione od Agencji Mienia Wojskowego przez Gminę Miejską Jarosław. Tereny te zostały przeznaczone na usługi kulturalnoadministracyjne bez udziału funkcji mieszkaniowej przy zachowaniu zakazu budowy obiektów handlowych. Decyzja taka była spowodowana chęcią ochrony blisko 400 sklepów rodzimych handlowców na terenie miasta Jarosławia. Ówczesne władze zdawały sobie sprawę, że w konfrontacji z wielkimi sieciami handlowymi jarosławscy kupcy są bezsprzecznie na przegranej pozycji. Jedynym sposobem ochrony ich miejsc pracy było niewpuszczenie marketów do miasta. W myśl tej koncepcji w latach 20022006 nie wydano żadnej zgody lokalizacyjnej. Jednak po wyborze nowej Rady Miasta w listopadzie 2006 r. zmieniła się całkowicie koncepcja rozwoju miasta i w krótkim czasie zgodzono się na budowę na terenach byłej jednostki dużej galerii handlowej, a także wielu innych sklepów w różnych częściach miasta. Obecnie Jarosław ma jedną $\mathrm{z}$ największych powierzchni handlowych w przeliczeniu na jednego mieszkańca w Polsce. Bardzo duży wzrost tych powierzchni w latach 2008-2014 doprowadził do ogromnej konkurencji i w konsekwencji do ruiny i osobistych tragedii wielu lokalnych przedsiębiorców. W artykule przedstawiono wyniki badań ankietowych dotyczących rozwoju lokalnej przedsiębiorczości w kontekście podjętych decyzji planistycznych i rozwoju sieci handlowych na terenach miasta Jarosławia.
\end{abstract}

Słowa kluczowe: rewitalizacja terenów powojskowych, MPZP

\footnotetext{
1 Autor do korespondencji/corresponding author: Janusz Dąbrowski, Państwowa Wyższa Szkoła Techniczno-Ekonomiczna w Jarosławiu, ul. Czarnieckiego 16, 37-500 Jarosław; e-mail: geostaszic@wp.pl

${ }^{2}$ Waldemar Paluch, Burmistrz Miasta Jarosławia, ul. Rynek 1, 37-500 Jarosław
} 


\section{Etapy zmian w MPZP terenów powojskowych przy ul. Piekarskiej}

Do 2003 r. właścicielem terenów po byłej jednostce wojskowej przy ul. Piekarskiej była Agencja Mienia Wojskowego. Teren zgodnie z uchwałą Rady Miasta przeznaczony był do specjalnego użytkowania i oznaczony symbolem B 92 IS. Uchwałą Nr 492/XXXIII/2001 z dnia 25 czerwca 2001 r. Rada Miasta Jarosławia wyraziła zgodę na zmianę Miejscowego Planu Ogólnego Zagospodarowania Przestrzennego m. Jarosławia dla obszaru obejmującego teren specjalny (kompleks wojskowy) [9]. Przedmiotem opracowania planu było określenie warunków użytkowania i zagospodarowania obszaru na cele usług kulturalnoadministracyjnych bez udziału funkcji mieszkaniowej oraz z zakazem budowy obiektów handlowych. Grunty po byłej jednostce wojskowej nabywano etapowo na drodze bezprzetargowej zazwyczaj za cenę wywoławczą.

Z dniem 31 grudnia 2003 r. Plan Miejscowy z 1992 r. utracił ważność. W dniu 23 kwietnia 2004 r. pomiędzy Gminą Miejską Jarosław, a inż. arch. Przemysławem Kotlińskim została zawarta umowa o dzieło na sporządzenie koncepcji programowo-przestrzennej zagospodarowania terenu położonego pomiędzy ul. Grunwaldzką, Sikorskiego, Słowackiego i Piekarską w Jarosławiu w ramach opracowań towarzyszących (faza przedprojektowa) sporządzeniu planu miejscowego przewidywanego obszaru. Ostatecznie projekt MPZP został wykonany przez Jeleniogórskie Biuro Planowania Przestrzennego i wyłożony do publicznego wglądu wraz z prognozą oddziaływania na środowisko w dniach od 6 listopada 2006 r. do 27 listopada 2006 r. Gotowy plan (rys. 1.) nie został jednak przedłożony Radzie Miasta do uchwalenia.

Po zmianie władz samorządowych w dniu 20 grudnia 2006 r., tj. po kilku tygodniach od ich wyboru, została spisana notatka służbowa dotycząca realizacji umowy na opracowanie planu miejscowego o treści: „Ze względu na konieczność wypracowania nowego programu użytkowego w obszarze objętym opracowaniem $i$ w konsekwencji nowego uktadu przestrzennego inwestycji, wstrzymuje sie prace projektowe nad tematem do czasu określenia $w / w$ programu przez Zamawiającego". Doszło do sytuacji kuriozalnej: gotowy plan wyłożony do publicznej dyskusji nie został wprowadzony pod obrady Rady Miasta i wszystkie prace rozpoczęto od nowa. Zmarnotrawiono tym samym niemałe środki publiczne, a sposób przeprowadzenia sprawy pozostawił wątpliwości o prawdziwe motywy podjętych działań.

Od momentu spisania notatki zmieniła się całkowicie koncepcja zagospodarowania terenów powojskowych. I tak uchwałą Rady Miasta Nr 82/X/07 z dnia 23 kwietnia 2007 r. w sprawie przystąpienia do sporządzenia zmiany $\mathrm{Nr}$ 1/1/2007 Studium uwarunkowań i kierunków zagospodarowania przestrzennego 


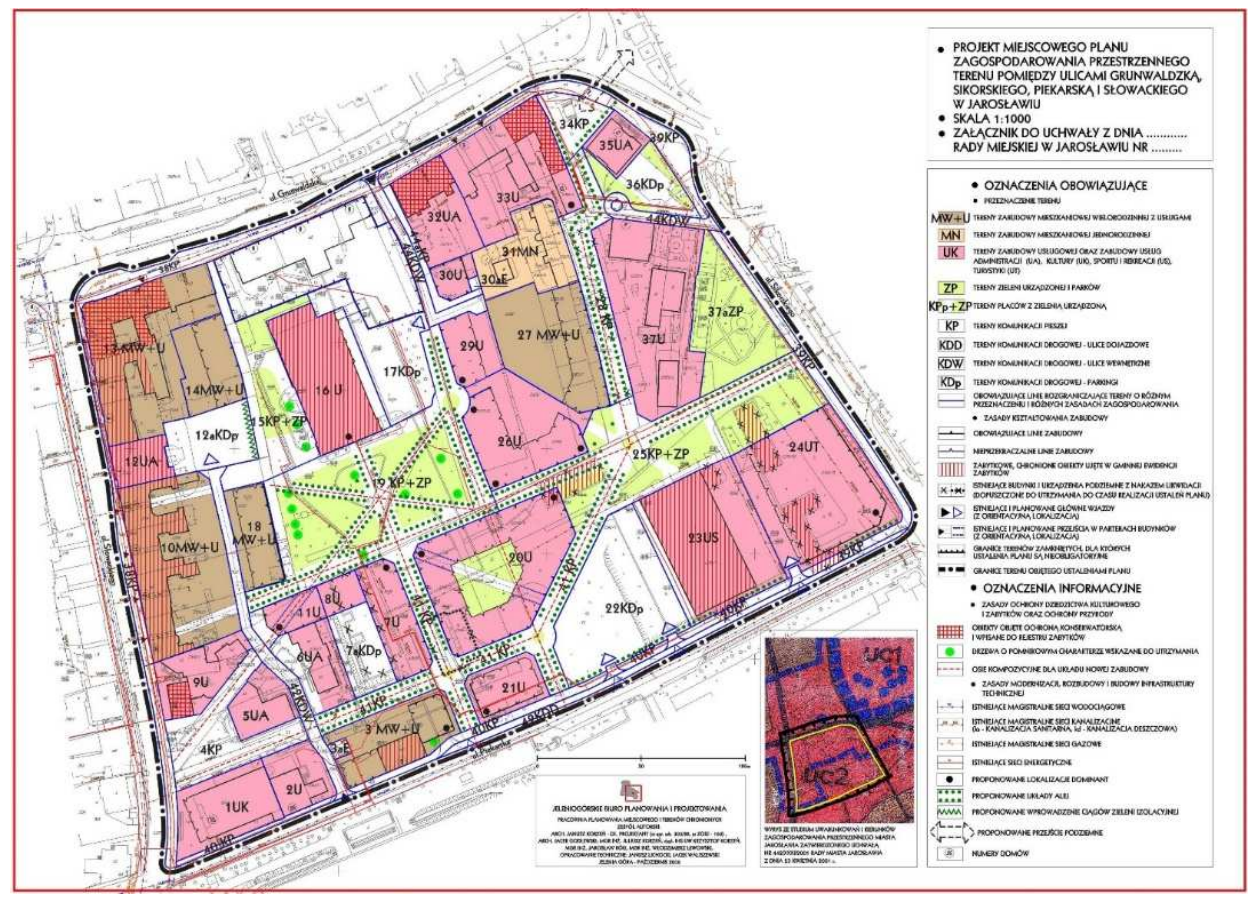

Rys. 1. Projekt MPZP wyłożony do publicznego wglądu 6.11.2006 r.

Rys. 1. Project of Local Spatial Development Plan set out at 6.11.2006 for public inspection.

m. Jarosławia w rejonie ul. Piekarskiej, umożliwiono lokalizację obiektu handlowego powyżej $2000 \mathrm{~m}^{2}$ [9]. W § 3 w/w uchwały wpisano, że w zmianie Studium określi się w szczególności obszar rozmieszczenia obiektu handlowego o pow. sprzedaży powyżej $2000 \mathrm{~m}^{2}$ oraz obszary przestrzeni publicznej. Zapis taki budził kontrowersje z uwagi istniejącą niewydolność komunikacyjną centrum miasta. Wielokrotnie poruszała ten fakt ówczesna Radna Pani Elżbieta Kluz na obradach RM. Lokalizacja galerii na ulicy Piekarskiej mogła tylko znacząco powiększyć blokadę komunikacyjną miasta. Ostatecznie decyzję podjęto bez jakichkolwiek badań na temat jej skutków dla istniejącego handlu. Ostateczna wersja projektu Miejscowego Planu Zagospodarowania Przestrzennego przy ul. Piekarskiej wraz z prognozą oddziaływania na środowisko została wyłożona do publicznego wglądu w dniach od 24 lipca 2008 r. do 22 sierpnia 2008 r. Uchwałą $\mathrm{Nr}$ 491/XLV/08 z dnia 19 grudnia 2008 r. Rada Miasta Jarosławia w obecności 15 radnych przy 1 głosie wstrzymującym podjęła uchwałę w sprawie uchwalenia Miejscowego Planu Zagospodarowania pomiędzy ul. Grunwaldzką, Sikorskiego, Słowackiego i Piekarską (rys. 2.). 


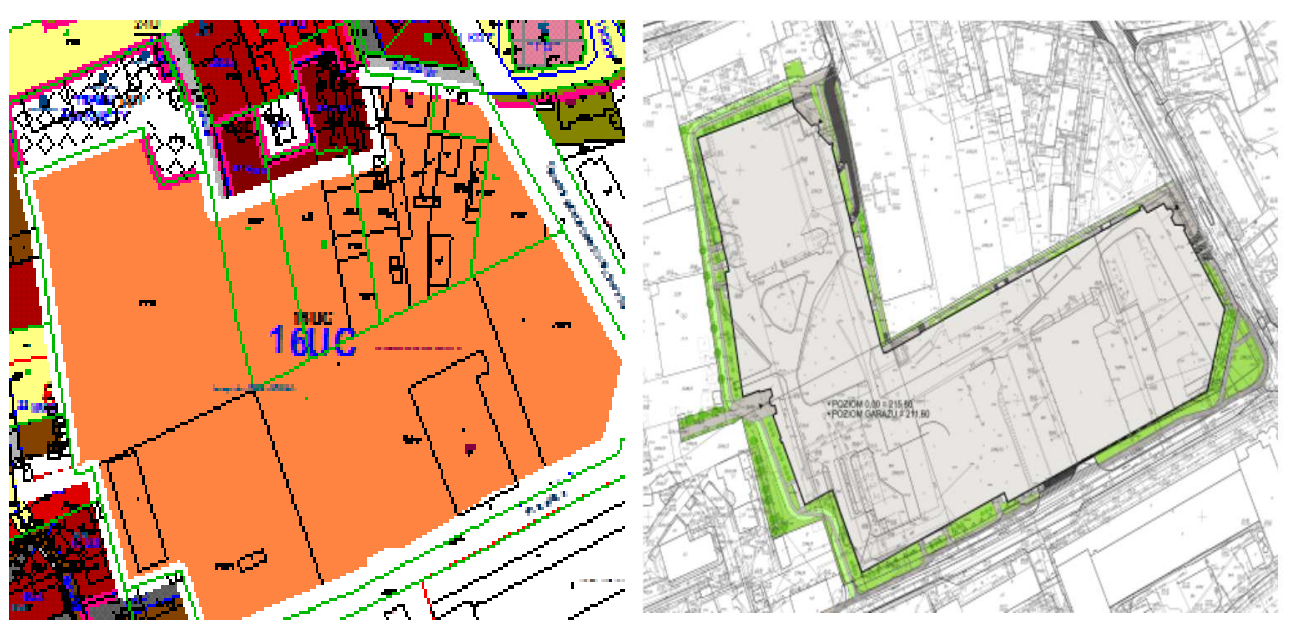

Rys. 2. Projekt MPZP uchwalony w dniu 19.12.2008 r. wraz z obrysem galerii

Rys. 2. Project of Local Spatial Development Plan enacted at 19.12.2008 r. along with mall outline.

Uchwalony w grudniu 2008 r. MPZP nie był jedyną zgodą na lokalizację sklepów sieciowych i wielkopowierzchniowych. W latach 2008-2014 powstało w Jarosławiu wiele nowych obiektów handlowych.

\section{Rozwój handlu na terenie miasta Jarosławia}

\subsection{Jarosław - historyczne miasto kupieckie}

Początki Jarosławia w opinii wielu historyków sięgają jedenastego wieku. Pierwsza źródłowa wzmianka o jego istnieniu pochodzi z 1152 r., z kroniki ruskiego kronikarza Nestora. Istnieją przypuszczenia, że założycielem grodu był książę kijowski Jarosław Mądry (1019-1054). Lokacja miasta na prawie magdeburskim w 1375 r. przyczyniła się do wzmożonego rozwoju miasta [4]. Już w pierwszej połowie XIV wieku Jarosław zaliczany był do najbogatszych miast Rusi. Bliskość spławnej rzeki San i położenie na kilku szlakach kupieckich uczyniły z Jarosławia znany ośrodek handlu i rzemiosła [5]. Do miasta zjeżdżali zamożni kupcy z różnych stron Europy, a nawet z Bliskiego Wschodu. Według opinii współczesnych, Jarosław był największym po Frankfurcie nad Menem ośrodkiem handlowym w ówczesnej Europie środkowo - wschodniej [7]. W 1501 r. miasto otrzymało ważny przywilej - prawo składu, zobowiązujący przejeżdżających kupców do zatrzymania się i wystawiania w Jarosławiu na sprzedaż przewożonych towarów. Sierpniowy jarmark jarosławski, zwany również wielkim, gromadził ponad 30 tys. osób w mieście liczącym 3 tys. miesz- 
kańców. Rozwijający się handel przyczynił się do wszechstronnego rozwoju miasta [10]. Okres największego rozkwitu Jarosławia przypada na XVI i pierwszą połowę XVII w. [8].

\subsection{Współczesne uwarunkowania rozwoju handlu w Jarosławiu}

Okres powojenny to wzmożony rozwój gospodarczy miasta i rozpoczęcie działalności dużych zakładów pracy takich jak Huta Szkła Jarosław (obecnie największa huta szkła Opakowaniowego w Europie), Zakłady Dziewiarskie „Jarlan”, Zakłady Przemysłu Cukierniczego „San”, Zakłady Mięsne (obecnie „Sokołów") i wiele innych. Okres transformacji po 1989 r., to masowe zamykanie przedsiębiorstw i likwidacja miejsc pracy. Wiele zwolnionych osób zmuszonych było do utworzenia sobie miejsca pracy. Na początku lat 90' XX wieku większość nowopowstałych działalności rozwijało się pomyślnie $\mathrm{z}$ uwagi na duże zapóźnienia w wielu dziedzinach i braki w ofercie na rynku. Powstało kilkaset podmiotów gospodarczych zajmujących się handlem. W mieście panował klimat sprzyjający rozwojowi rodzimej przedsiębiorczości. Taka sytuacja utrzymywała się do końca 2006. Później rozpoczął się etap silnego-wzrostu powierzchni handlowej: z 28 tys. $\mathrm{m}^{2} \mathrm{w} 2000 \mathrm{r}$. do 59 tys. $\mathrm{m}^{2} \mathrm{w} 2014 \mathrm{r}$.

Na początku XXI w. Jarosław był miastem lokalnych handlowców. Ich sytuacja zmieniła się radykalnie po 2013, w którym w odległości 1 km od centrum miasta działały już 34 sklepy sieciowe i wielkopowierzchniowe, a dodatkowo 7 powyżej $1 \mathrm{~km}$ od centrum. W tym czasie zinwentaryzowano blisko 400 małych rodzimych sklepów.

W 2014 r. w trakcie przygotowania były budowy galerii na ulicy Piekarskiej, Krakowskiej, Przemysłowej, Głębokiej i na terenie dworca autobusowego. Większość nowo planowanych lokalizacji mieści się w centrum Jarosławia. W sytuacji kiedy powierzchnia handlowa w przeliczeniu na jednego mieszkańca w Jarosławiu była już znacząco większa niż w Warszawie, Poznaniu, Wrocławiu czy Krakowie, jest niemal pewne - potwierdzają taki scenariusz doświadczenia z innych miejsc na świecie, że spośród rodzimych kupców przetrwają nieliczni i po pewnym czasie zacznie się wyniszczająca walka pomiędzy dużymi sieciami [1]. Wszelkie dane mówią o zbliżającym się poważnym kryzysie w tej branży. Niestety, już dziś wiadomo, że w „wojnie o handel” głównymi przegranymi będą drobni przedsiębiorcy.

Konsekwencje zarysowanej powyżej sytuacji mogą spowodować w przyszłości bardzo silną zmianę wizerunkową miasta. Po osiągnięciu apogeum około 2020 należy oczekiwać silnego ograniczenia inwestycji handlowych, po którym pojawi się na szeroką skalę zjawisko niewykorzystanych powierzchni handlowych, które zdaniem autorów przekroczy $30 \%$ ich ogólnego stanu posiadania w Jarosławiu. Taka sytuacja może wpłynąć bardzo źle na wizerunek miasta. Mogą pojawić się lokale w centrum miasta o zaniedbanym wyglądzie, ponieważ właścicieli nie będzie stać na ich remont. 
Taki rozwój wydarzeń jest szeroko opisany w branżowych czasopismach [6]. Ówczesne władze miasta, bez wykonania jakichkolwiek obiektywnych prognoz, pozwoliły jednak na niczym nie kontrolowany rozwój sieci handlowych. Zmiana koncepcji zagospodarowania terenów powojskowych i jej konsekwencje w dłuższym okresie czasu przyczynią się do stopniowego likwidowania rodzimego handlu, co może odbić się fatalnie na rozwoju miasta.

Po przeprowadzeniu badań ankietowych na temat satysfakcji z prowadzonej działalności wśród handlowców okazało się, że zdecydowana większość z nich najchętniej zaprzestałaby swojej działalności. Wśród przyczyn dla, których tego nie robią najczęściej wymieniane są: brak możliwości innej pracy, obawa o straty wywołane brakiem możliwości zbycia swoich towarów (często oszczędności całego życia), niemożność dostosowania się do nowych warunków (zamiana roli z pracodawcy na pracownika najemnego) i chęć „dotrwania” do emerytury. Wyniki ankiety badania satysfakcji przedstawiono poniżej na rys. 3 .

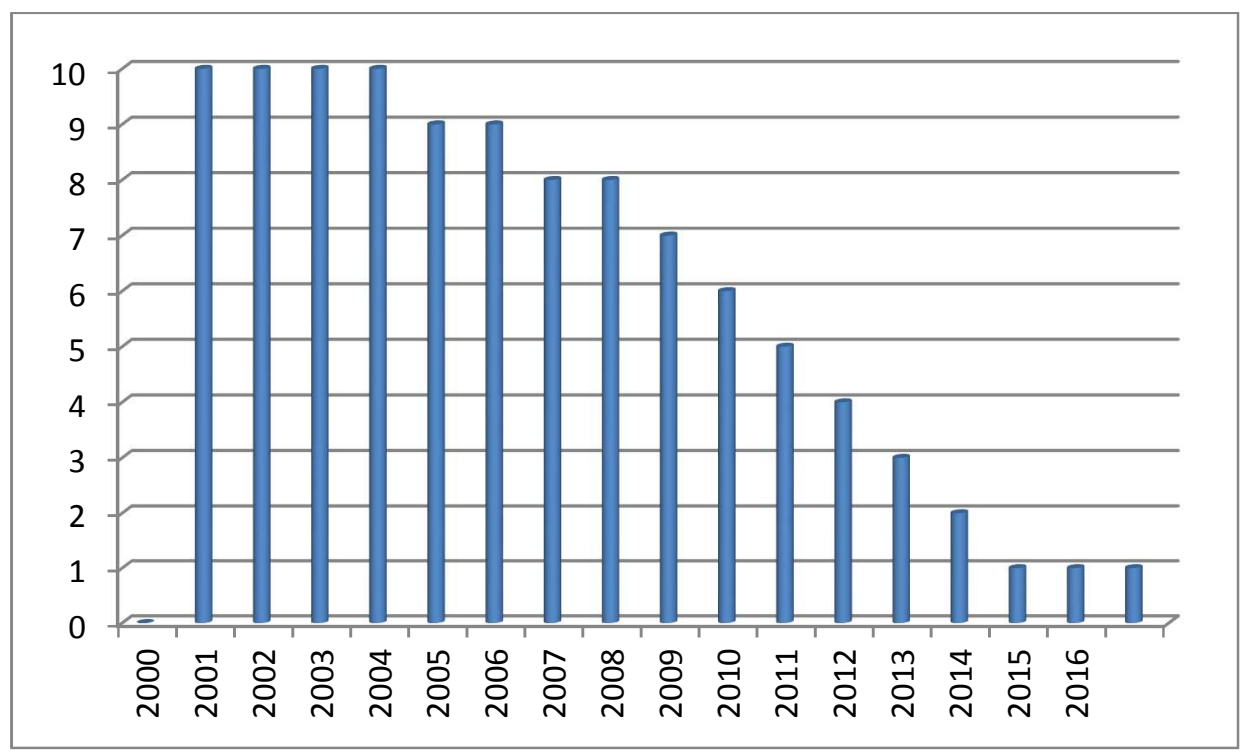

Rys. 3. Poziom satysfakcji handlowców w latach 2000-2016

Rys. 3. Merchants satisfaction level in 2000-2016

W dziesięciostopniowej skali ocena dziesięć oznacza bardzo wysoki poziom satysfakcji z prowadzonej działalności. Można zatem przyjąć, że do roku 2009 handlowcom wiodło się w miarę dobrze. Po 2012 roku satysfakcja z prowadzonej działalności znacząco się obniżyła. Badania ankietowe prowadzone w 2012 r. w ocenie handlowców wykazały, że już w 2012 r. nie widzieli sensu prowadzenia działalności. Te same badania powtórzone w 2016 r. pokazały, że 
przedsiębiorcy najgorzej oceniają lata 2015-2016, co znaczyłoby, że ich sytuacja znacząco się pogorszyła w stosunku do $2012 \mathrm{r}$.

\section{Podsumowanie}

W Jarosławiu można pokazać przykłady pozytywnego jak i negatywnego sposobu zagospodarowania terenów powojskowych. Pozytywnym przykładem jest teren zagospodarowany dla działalności Państwowej Wyższej Szkoły Techniczno-Ekonomicznej w Jarosławiu [2]. Otworzenie uczelni z inicjatywy Senatora Andrzeja Tadeusza Mazurkiewicza przyczyniło się do rozwoju miasta. Negatywnym przykładem jest zagospodarowanie terenów powojskowych na ulicy Piekarskiej. Lokalizacja sklepów sieciowych i wielkopowierzchniowych w pobliżu centrum miasta jest działalnością szkodliwą, co pokazały liczne przykłady z wielu miastach Polski i Europy. Wielki biznes będzie zawsze dążył do optymalizacji prowadzonej działalności i maksymalizacji zysku. Jest to zupełnie naturalne i pragmatyczne podejście dużego kapitału. Niestety państwo i samorządy nie wypracowały skutecznych mechanizmów obronnych i w praktyce w zdecydowanej większości wypadków przegrywają walkę o swoje interesy [6]. Przykład zachowania Radnych Miasta Jarosławia pokazał całkowity brak troski o istniejące miejsca pracy i los wielu mieszkańców prowadzących działalność gospodarczą. W zaistniałej sytuacji tylko nieliczni przedsiębiorcy mogli zamknać prowadzoną działalność i przebranżowić się. Niestety wielu nie miało takiej możliwości i ciągle liczy na „cud” i zmianę ich sytuacji, nie biorąc pod uwagę, że każdy kolejny rok tylko pogarsza ich sytuację. Nie przyniosły też żadnych skutków próby integracji rodzimego kapitału w latach 2012-2014. Podziały pomiędzy ludźmi i wzajemna nieufność spowodowały, że zaprzepaszczono ostatnią szansę obrony przed wielkim kapitałem, jakim było powołanie konsorcjum lub spółki skupiających jarosławskich handlowców. Na zaproszenie 400 handlowców na spotkanie organizacyjne odpowiedziało tylko 7 osób. Brak wiary zaistniałą sytuacją mógł także spowodować u wielu przedsiębiorców tzw. „efekt wyparcia”. Autorzy na podstawie przeprowadzonych obserwacji stwierdzili bardzo analogiczne działania w wielu miastach Podkarpacia i Polski. Większość nowopowstałych obiektów handlowych została sfinansowana z kredytu hipotecznego. Jest pewne, że powstanie nowych galerii w centrum miasta spowoduje nie tylko wzmożony upadek małych sklepów, ale przyczyni się do zamykania już istniejących nowych obiektów, co może spowodować, niemożność spłaty zaciągniętych kredytów inwestycyjnych. W skali kraju może to zapoczątkować duży kryzys bankowy. Jeżeli w Jarosławiu łączna suma kredytów zaciągniętych na cele inwestycji mieszkaniowych wynosi około $100 \mathrm{mln}$ zł to odpowiada to kosztom budowy jednej galerii. Od kilku lat ilość pieniądza na rynku jarosławskim jest na podobnym poziomie. W ciągu ostatnich kilkunastu lat odnotowuje się odpływ młodych ludzi. Jeżeli w takich warunkach powierzchnia 
handlowa wzrasta trzykrotnie to nie jest możliwe dalsze funkcjonowanie handlu w niezmienionym wymiarze. Większość lokali handlowych jest budowana przez inwestorów i później wynajmowana dużym sieciom. W przypadku spadku obrotów sieci handlowe w umowach zastrzegają sobie możliwość zerwania umowy najmu. Ostatecznie spowoduje to, że w mieście będzie wiele lokali bez żadnych szans na wynajem [3]. Ten stan rzeczy odbije się na wizerunku miasta. Wielu właścicieli nie będzie stać na remont lokali generujących straty. Dodatkowo długotrwałe pustostany będą ,prowokowały dzikich lokatorów” do działań pozaprawnych. Rozwijająca się sprzedaż internetowa wzmocni negatywne trendy. Można z dużym prawdopodobieństwem stwierdzić, że podjęte działania planistyczne przyniosą bardzo złe skutki dla miasta. Ostatecznie ucierpi gospodarka, demografia i wiele osób popadnie w tarapaty finansowe i stanie w obliczu finansowej katastrofy. Jest wielce prawdopodobne (według autorów wręcz pewne), że sieci handlowe uzgodnią podział rynku i zoptymalizują liczbę sklepów na terenie miasta, co spowoduje likwidację nawet dochodowych sklepów i przyniesie dodatkowe zyski korporacjom z uwagi na znaczącą redukcję kosztów stałych. W takich warunkach wielu właścicieli lokali handlowych może otrzymać propozycję od sieci handlowych ,nie do odrzucenia” odkupienia lokali za np. za 50\% ich wartości lub ,śmiesznie niskiego” czynszu.

\section{Wnioski końcowe}

1. Lokalizacja na terenach wojskowych galerii handlowej spowoduje silną zmianę w strukturze gospodarczej miasta, komunikacji i wizerunku miasta.

2. Nastąpi duża redukcja liczby sklepów i podmiotów prowadzących działalność handlową.

3. Pustostany lokali handlowych mogą przekroczyć $30 \%$ całkowitej powierzchni handlowej.

4. Przykład Jarosławia pokazuje, że rewitalizacja terenów wojskowych musi być przeprowadzona $\mathrm{z}$ uwzględnieniem sytuacji społecznogospodarczej danego miasta.

5. Budowa galerii i umożliwienie działalności sieciom handlowym w centrum miasta okazała się równoznaczna $\mathrm{z}$ systematyczną likwidacją rodzimego handlu.

6. Przedsiębiorcy nie widzą związku pomiędzy decyzjami planistycznymi przez konkretnych radnych i ich osobistą sytuacją. Na podstawie ich wypowiedzi zawartych $\mathrm{w}$ ankietach można sądzić, że odpowiedzialność za obecny stan rzeczy jest całkowicie rozmyta. Dowodem na postawioną tezę jest fakt, że wielu z nich zostało ponownie wybranych. 
7. Najbardziej poszkodowanymi z zaistniałej sytuacji poza osobami, które stracą miejsce pracy będą właściciele niespłaconych stosunkowo nowych lokali, które będą nosiły miano „trwałych pustostanów”. Konieczność spłaty kredytów bez źródła dochodu spowoduje osobiste komplikacje wielu rodzin na terenie miasta Jarosławia.

8. W ostatecznym rozrachunku mogą zmniejszyć się wpływy do budżetu miasta.

\section{Literatura}

[1] Bydłosz Jarosław i in. (2010): Fiscal impact of selected legislative solutions in Poland on sustainable development in the context of the real estate market analysis. SGEM 2010 : 10th International Multidisciplinary Scientific Geoconference: conference proceedings, Vol. 2. Sofia : STEF92 Technology Ltd., cop. 2010. ISSN 13142704; ISBN 978-954-91818-1-4. S. 1165-1172.

[2] Dąbrowski Janusz i in. 2013. Badania relacji pomiędzy działalnością i rozwojem wyższej uczelni a elementami rynku nieruchomości miasta Jarosław: raport z badań : monografia - Research on relationships between the activity and development of college and components of real estate market in Jarosław / Jarosław : Państwowa Wyższa Szkoła Techniczno-Ekonomiczna, 2012-2013. - 221 s. - Bibliogr. s. 219221. - ISBN: 978-83-63909-00-0. - J. Dąbrowski - dod. afiliacja: PWSTE

[3] Dąbrowski Janusz, FIREK Karol (2013) The assessment of real estate market as an economic tool affecting the protection of environment, W: SGEM2013 : GeoConference on Ecology, economics, education and legislation, Albena, Bulgaria s. 293-300. ISSN 1314-2704). - ISBN: 978-619-7105-05-6. — s. 293-300. — Bibliogr. s. 299-300.

[4] Głowacki Z. 1997. Przewodnik historyczny po wzgórzu św. Mikołaja w Jarosławiu. Kieferling K., Kostka-Bieńkowska Z., Warto zobaczyć. Mini przewodnik po Jarosławiu, Wyd. UMJ, Jarosław

[5] Kamieniecki M. 1999. Jarosław gród nad Sanem. Perła Podkarpacia, „Nasz Dziennik w Jarosławiu". s. 3

[6] Parzych Piotr i in. (2013). Analysis of additional economic parameters necessary to grant a loan to Local Government Units based on real estate market analysis. 13 th International Multidisciplinar Scientyfic GeoConference SGEM 2013 Bułgaria. Environmental legislation, multilateral relations and funding opportunities. - Sofia

[7] Strzelicki Z. i in. 1976. Miasta. które mogły zaginąć.Wiedza Powszechna Warszawa

[8] Sroka A. 2005. Świątynie Jarosławia. Wyd. JKSCH im. O. Pio. Jarosław

[9] http://www.jaroslaw.pl

[10] http://www.mok-jar.pl/ 


\section{DETERMINATION OF THE IMPACTS OF FORMER MILITARY AREAS REVITALIZATION INTO COMMERCIAL ACTIVITIES IN JAROSŁAW}

\section{S u m m a r y}

The authors have described the process of enacting a Local Spatial Development Plan for a former military unit. Nearly 4 hectares of land in the city center were purchased from the Military Property Agency by the Jarosław Municipal Commune. These areas were devoted to cultural and administrative services without the housing function and with the ban on the construction of shopping facilities. This decision was undertaken due to the desire to protect nearly 400 shops of local traders in Jarosław. The authorities were aware that, in confrontation with large trading networks, the Jaroslaw merchants had no chance of competing. The only concept of protecting their workplaces was the strict blocking of the town from the invasion of the markets. According to this concept, no location consent was issued in 2002-2006. Unfortunately, after the selection of the new City Council in November 2006, the concept of city development completely changed, and in the short term administration agreed to build on this site large shopping mall and many other shops in different parts of the town. Currently, Jarosław has one of the largest retail space per capita in Poland. Very high growth in retail space in the years 2008-2014 has led to enormous competition and consequently to the ruin and personal tragedy of many local entrepreneurs.

The paper presents the results of survey research on the development of local entrepreneurship in the context of the planning decisions and the development of retail chains in the Jarosław territory.

Keywords: Military areas revitalization, Local Spatial Development Plan

Przestano do redakcji: 09.06.2017 r.

Przyjęto do druku: 01.09.2017 r. 